\title{
TIMING OF MIGRATION AND EXCEPTIONAL GROWTH OF YOY ALOSA FALLAX RHODANENSIS (ROULE, 1924) IN A LAGOON IN SOUTHERN FRANCE.
}

\author{
A.J. CRIVELLI, G. POIZAT \\ Station Biologique de la Tour du Valat, Le Sambuc, 13200 ARLES, France. \\ E-mail : a.crivelli@tour-du-valat.com
}

Reçu le 31 juillet 2000

Accepté le 17 janvier 2001

Received 31 July, 2000

Accepted 17 January, 2001

\begin{abstract}
The Vaccarès lagoon in the diked Rhône delta is the only lagoon in southern France out of 28 lagoons where a large population of YOY (young of the year) shad occurs every year from June-July to November-March depending on the year. This peculiar case can be explained on one hand by the nearby spawning ground in the River Rhône and its tributaries and on the other hand by a nocturnal recruitment of the YOY shad from the River Rhône to the diked Rhône delta through water pumped for rice farming. The timing of the appearance and growth of YOY shad were studied for six years. YOY began to enter through pumps in mid-June or mid-July depending on the year, with fork lengths ranging between $20-55 \mathrm{~mm}$. Growth was nearly linear from mid-July to mid-December, and the growth rate (regression slope) varied significantly between years, from 0.9 to $1.4 \mathrm{~mm} . \mathrm{d}^{-1}$. Maximum observed total lengths of YOY were $213 \mathrm{~mm}$, and mean total length of YOY at the end of the growing season was $182.9 \mathrm{~mm} \pm 24$.3. Growth seemed to stop in winter. The date at which YOY disappeared from catches in the Vaccarès lagoon varied between years, from mid-November to mid-March. YOY seemed to leave the lagoon after the first cold weather (air temperature $<0^{\circ} \mathrm{C}$ ). YOY growth observed in the Vaccarès lagoon is much higher than the growth recorded in Atlantic France and in northern Europe.
\end{abstract}

Key-words : Alosa fallax, YOY, French Mediterranean lagoon, growth.

\section{PÉRIODE D'OCCURRENCE ET CROISSANCE EXCEPTIONNELLE DES JEUNES DE L'ANNÉE D'ALOSA FALLAX RHODANENSIS (ROULE, 1924) DANS UNE LAGUNE DU SUD DE LA FRANCE.}

\section{RÉSUMÉ}

L'étang du Vaccarès situé dans le delta du Rhône endigué est la seule des 28 lagunes méditerranéennes françaises à abriter annuellement une population abondante d'alosons de juin-juillet à novembre-mars selon les années. Ce cas particulier s'explique, d'une part par la présence proche de zone de frai de l'alose sur le Rhône et ses affluents 
et d'autre part par un recrutement nocturne d'alosons dans le delta du Rhône endigué par pompage de l'eau du Rhône pour l'irrigation des nombreuses rizières du delta. La période d'occurrence et la croissance des alosons ont été étudiées pendant six ans. Les premiers alosons sont recensés dans les pompes de la mi-juin à la mi-juillet et leurs longueurs à la fourche varient entre 20 et $55 \mathrm{~mm}$. La croissance des alosons dans le delta du Rhône est linéaire de la mi-juillet à la mi-décembre, et le taux de croissance varie entre 0,9 et $1,4 \mathrm{~mm} . j^{-1}$ selon les années. Le plus grand aloson mesuré faisait $213 \mathrm{~mm}$ en longueur totale et la longueur totale moyenne des alosons à la fin de la saison de croissance était de $182,9 \mathrm{~mm} \pm 24,3$. La croissance s'arrête dès le début de l'hiver. Les alosons semblent quitter l'étang du Vaccarès dès les premiers froids entre novembre et mars (température de l'air inférieur à $0^{\circ} \mathrm{C}$ ). La croissance des alosons dans le delta du Rhône est supérieure à celles observées pour cette espèce dans les rivières de l'Europe du nord et de France atlantique.

croissance.

Mots-clés : Alosa fallax, jeune de l'année, lagune méditerranéenne française,

\section{INTRODUCTION}

Shad are rare in all the French Mediterranean lagoons, which cover some 68000 ha and only a few immature or adult fish enter these coastal wetlands accidentally (GOURRET, 1897 ; QUIGNARD and ZAOULI, 1980, 1981 ; BOURQUARD, 1985 ; QUIGNARD, pers. comm.).

The Rhône subspecies of the twaite shad, Alosa fallax rhodanensis is an anadromous clupeid that spawns in the Rhône and its tributaries, in the rivers Aude and Hérault and probably in some coastal rivers in Corsica (MENELLA, pers. comm.). The validity of the subspecies is still debatable, although it is certainly the twaite shad (LE CORRE et al., 1998). There have been several studies on this species, dealing with its taxonomy, status, migrations and its biology (RAMEYE et al., 1976 ; QUIGNARD and KARTAS, 1977 ; DOUCHEMENT, 1981 ; QUIGNARD and DOUCHEMENT, 1991 ; LE CORRE et al., 1997). Although the biology and ecology of spawning shad in the Rhône is well known (LE CORRE et al., 1997) practically nothing is known about the migration and the growth of young of the year in this population. QUIGNARD (1977) described the downstream migration in the Rhône as occurring in September-October, whereas TABARDEL, MENELLA and GENDRE (1995) and GENDRE, MENELLA and CORRAO (1997) stated that the downstream migration took place from the end of August to the end of October.

YOY shad are difficult to sample in rivers (THIEL, SEPULVEDA and OESMANN, 1996 ; GENDRE, MENELLA and CORRAO, 1997), particularly in large fast-flowing rivers. Most existing data have therefore been collected by sampling the cooling water entering nuclear or fossil-fuel power stations occurring along rivers (CLARIDGE and GARDNER, 1978 ; APRAHAMIAN, 1988 ; TAVERNY, 1990 ; GENDRE, MENELLA and CORRAO, 1997). This explains why there are few data on the growth of YOY shad and on the timing of their migration. In the Severn estuary (U.K.), at about $30 \mathrm{~km}$ from the sea CLARIDGE and GARDNER (1978) and APRAHAMIAN (1988) reported the first YOY shad from the end of August onward. In the lower reaches (at ca $20 \mathrm{~km}$ from the sea) of the Elbe estuary (Germany) the first YOY shad were observed in August, the migration being completed in October (THIEL, SEPULVEDA and OESMANN, 1996). In the Gironde estuary (France), the first young twaite shad appeared in July (TAVERNY, 1990). American shad occurring along the Atlantic coast perform their downstream migration between June and November (O'LEARY and KYNARD, 1986 ; LIMBURG, 1996). 
In this article, we will attempt to answer the following two questions : (a) why is the Vaccarès lagoon the only French Mediterranean lagoon to harbour an abundant population of YOY shad ? and (b) what is the growth and timing of the migration of YOY shad occurring in the Rhône delta?

\section{MATERIAL AND METHODS}

The fish communities of several compartments of the Rhône delta aquatic system were sampled monthly from January 1993 to December 1999, using fyke nets with a mesh size of 5-6 mm that were emptied daily for 4 consecutive days. These compartments were the Aube de Bouic irrigation canal, the Fumemorte drainage canal, and a lagoon with two stations, La Capelière in the Vaccarès and the Malagroy in the lower lagoons (Figure 1). In addition, sampling of fish recruitment was conducted from 1997 to 1999 at three pumping stations, the Aube de Bouic, Le Sambuc and Grand Manusclat, situated along the river respectively at about 33, 25 and $21 \mathrm{~km}$ from the mouth of the Grand Rhône, the major distributary. This sampling was conducted using fish traps installed three weeks per month throughout the rice irrigation season (April to early October) (POIZAT et al., 1999). To augment our monthly catches of YOY shad in the Vaccarès, we also used the catches of a professional fisherman who used fyke nets identical to ours. During the study, the water pumped from the Rhône and in the irrigation canal was fresh, the mean annual salinity of the Fumemorte was $2 \mathrm{~g} / \mathrm{l}$ and that of the Vaccarès varied from $4.7 \mathrm{~g} / \mathrm{l}$ in 1996 to $14.0 \mathrm{~g} / \mathrm{l}$ in 1993 (Data from the Réserve Nationale de Camargue). From 1997 to 1999, the discharge of the Rhône during the pumping season varied from 289 to $3407 \mathrm{~m}^{3} / \mathrm{s}$ (Data from CNR).

All the YOY shad (caught either by our own sampling or caught by the fishermen) were measured (fork length) to the nearest millimetre and weighed (fresh weight) to nearest gram. On a sub-sample of 174 YOY shad with fork lengths of between 23 and $192 \mathrm{~mm}$, we also measured the total length. The correlation between the two measurements was :

$$
\mathrm{TL}=1.1343^{\star} \mathrm{FL}-0.08081, \mathrm{r}^{2}=0.9989, \mathrm{p}<0.001
$$




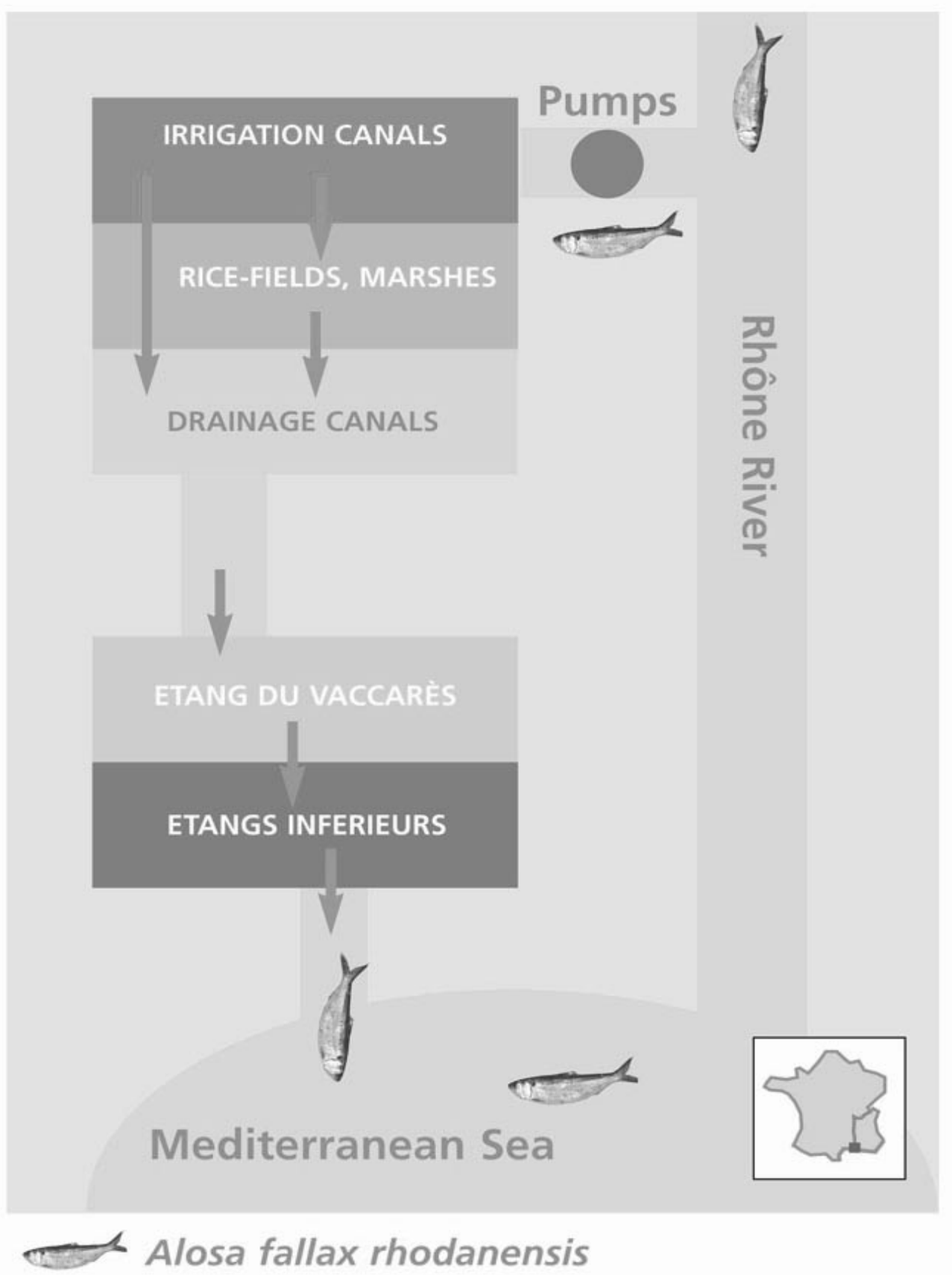

\section{Figure 1}

Diagrammatic representation of the route taken by young shad in the Rhône delta aquatic system.

\section{Figure 1}

Représentation schématique du cheminement des alosons dans l'hydrosystème du delta du Rhône. 


\section{RESULTS}

\section{Timing of the downstream migration of YOY in the Rhône delta}

YOY shad appeared in the pumps as early as the last week in June in 1997 and 1998 and as late as mid-July in 1999, i.e. 3-5 weeks after spawning ceased in the areas situated furthest downstream in the Rhône (Figures 1 and 2). The latter are located $30 \mathrm{~km}$ upstream of the pumps at le Sambuc. Usually most of the recruitment occurred between mid-June and mid-July depending on the year, but YOY shad were still being pumped in small quantities in August, and more rarely in September. Most of the YOY shad were pumped at night. The mean daily water temperature of the Rhône water at the peak of captures between 15 June and 15 July was $19.0^{\circ} \mathrm{C}$ in $1997,21.3^{\circ} \mathrm{C}$ in 1998 and $20.2^{\circ} \mathrm{C}$ in 1999 (Data from CNR).

\section{Year \& sites June July August September October November December January February}

$1997-1998$

Pumping stations

Irrigation canal

Drainage canal

Vaccarès lagoon
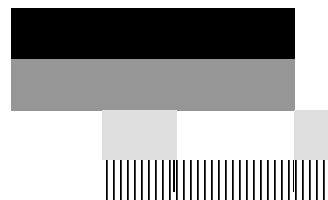

1998-1999

Pumping stations

Irrigation canal

Drainage canal

Vaccarès lagoon

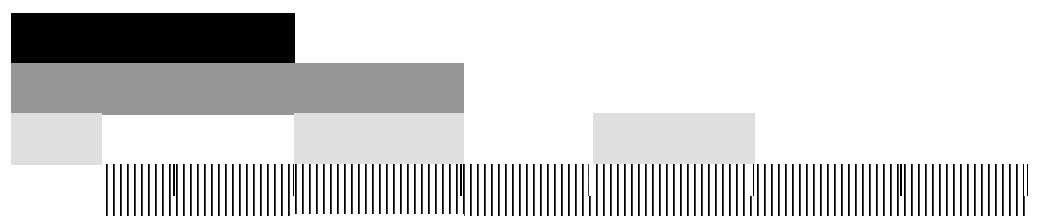

$1999-2000$

Pumping stations

Irrigation canal

Drainage canal

Vaccarès lagoon

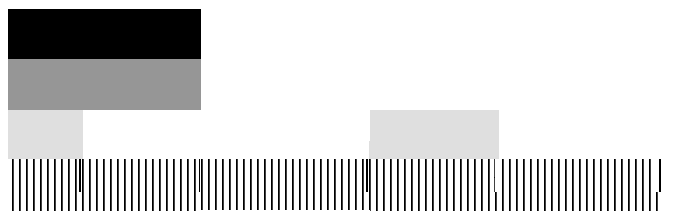

\section{Figure 2}

Occurrence of YOY shad in the four compartments of the Rhône delta aquatic system from 1997 to 2000.

\section{Figure 2}

Occurrence des alosons de 1997 à 2000 dans quatre compartiments de l'hydrosystème du delta du Rhône. 
In the three compartments of the catchment basin of the Vaccarès lagoon (pumps, irrigation and drainage canals), in which we counted YOY shad, the modal length was $3 \mathrm{~cm}$ in June-July for th years 1997-1999. In the Vaccarès lagoon, in July 1997-1999 the modal length is between $3.5 \mathrm{~cm}$, showing that the YOY shad dispersed very quickly downstream to reach the Vaccarès lagoon as quickly as possible (Figure 1 and 3 ). Once they had colonised the lagoon, they had no choice but to stay there until October (for the cohort 1993, 1995, 1996), until November (for the cohort 1999) and until January of the following year (for the cohort 1997 and 1998) since the connection with the sea, at the Grau de la Fourcade, was closed until then. We do not know whether the YOY shad would have left or remained in the Vaccarès if they had been physically capable of migrating to the sea from July onward. As they had no choice they remained and grew in the lagoon, and apparently found conditions excellent for growth in this environment. As soon as the first cold weather occurred (air temperature below $0^{\circ} \mathrm{C}$ ), the YOY shad left the lagoons provided the sluices were open. In the seven years we studied, the YOY shad left the system in November-December on three occasions and on four occasions between January and March of the following year.

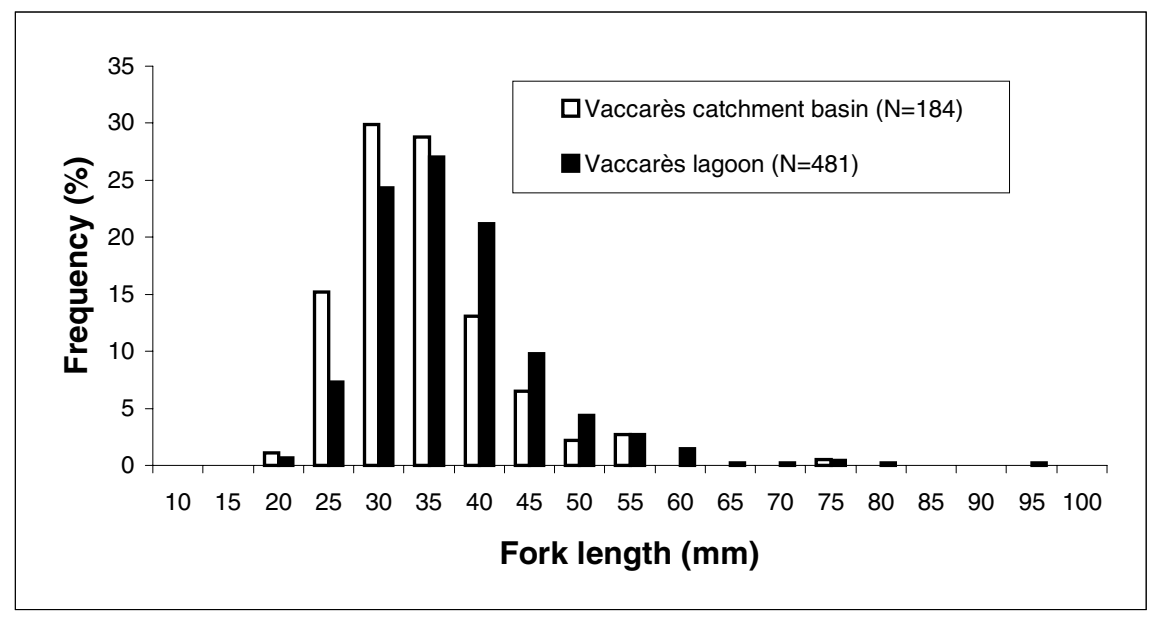

\section{Figure 3}

Size distribution of YOY shad in June-July 1997-1999 in the Vaccarès catchment basin (pumping from the Rhône river, irrigation and drainage canals) and in the Vaccarès lagoon.

\section{Figure 3}

Distributions des tailles d'alosons en juin-juillet 1997-1999 dans le bassin versant du Vaccarès (pompage au Rhône, canaux d'irrigation et de drainage) et dans l'étang du Vaccarès.

\section{Growth}

From 1993 to 1999 we measured 2159 YOY shad in the various compartments studied. Growth was linear during the period from 17 July (day 197) to 17 December (day 350), the period in which fish were present in all years (Figure 4 and Table I). The mean water temperature within the Vaccarès lagoon, from 17 July to 17 December varied between years from $15.8^{\circ} \mathrm{C}$ in 1996 to $19.6^{\circ} \mathrm{C}$ in 1993 . When the YOY shad remained longer in the system, as for example in 1995 and 1997, a slowing of the growth rate was observed from early November and the fish continued to have the same length until March. During the period of constant length the water temperatures were below $10-11^{\circ} \mathrm{C}$. The 
maximum recorded length of a YOY shad was $213 \mathrm{~mm}$ total length and the mean total length of YOY at the end of the growing season (November-December) for those years when the sluices were closed up to January (cohort 1997 and 1998) was $182.9 \mathrm{~mm} \pm 24.3$, with a mean weight of $53.9 \pm 22.4 \mathrm{~g}$. The growth rate (measured by the slope, Table I) varied between 0.9 and $1.4 \mathrm{~mm}$ day $^{1}$ and differed significantly between years (test of homogeneity of slopes : $p<0.0001 ; F_{5,1686}=21.1$ ) and suggested 3 groups : low growth in 1993 and 1996, average in 1995, 1997 and 1998 and high in 1999. Neither the temperature (degree-days), nor the salinity, nor the density of YOY shad expressed as the CPUE could explain these differences.

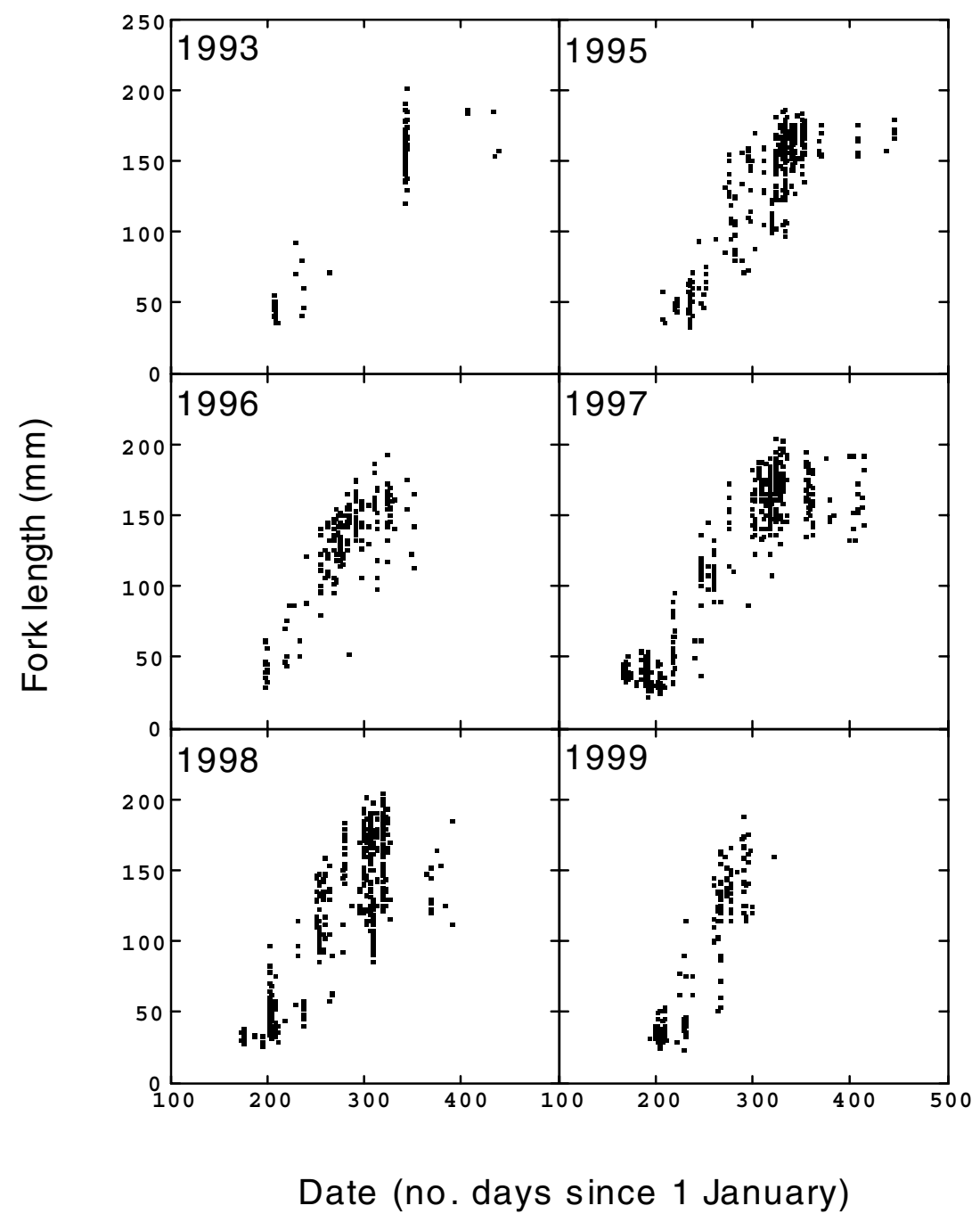

\section{Figure 4}

Growth of YOY shad from 1993 to 1999 in the Vaccarès lagoon.

\section{Figure 4}

Croissance des alosons de 1993 à 1999 dans l'étang du Vaccarès. 


\section{Table I}

Linear growth of YOY shad in the Vaccarès lagoon from 17 July to 17 December 1993-1999.

\section{Tableau I}

Croissance linéaire des alosons de l'étang du Vaccarès du 17 juillet au 17 décembre 1993-1999.

\begin{tabular}{llcccc} 
Year & $\mathbf{N}$ & intercept a (SE) & slope b (SE) & $\mathbf{R}^{2}$ & $\mathbf{P}$ \\
\hline 1993 & 108 & $-136(7.4)$ & $0.864(0.024)$ & 0.927 & $<0.0001$ \\
1995 & 325 & $-180(8.3)$ & $1.010(0.027)$ & 0.815 & $<0.0001$ \\
1996 & 183 & $-110(12.0)$ & $0.855(0.043)$ & 0.688 & $<0.0001$ \\
1997 & 343 & $-173(6.3)$ & $1.066(0.021)$ & 0.879 & $<0.0001$ \\
1998 & 505 & $-158(7.3)$ & $1.023(0.026)$ & 0.753 & $<0.0001$ \\
1999 & 234 & $-248(9.5)$ & $1.357(0.040)$ & 0.834 & $<0.0001$ \\
\hline
\end{tabular}

\section{Comparison of the growth of YOY shad in the Rhône and the Vaccarès}

In September 1994, GENDRE, MENELLA and CORRAO (1997) captured YOY shad in the turbine shaft of the Sauveterre hydroelectric dam, to the north of Avignon, on three occasions to monitor their downstream migration and growth. Only the fishing conducted on 10 September 1994 caught a large number of YOY shad. Their data, almost the only ones on YOY shad captured in the Rhône, were compared with the lengths of YOY shad captured in the Vaccarès at the same time of year (Figure 5). A significant difference was observed between the two sites; the YOY shad from the Vaccarès were much larger than those from the Rhône $\left(p<0.001 ; X^{2}=703.46\right.$; DF = 32). Consequently, the lengths of YOY shad from the Vaccarès cannot be considered as representative of the populations of YOY shad from the Rhône.
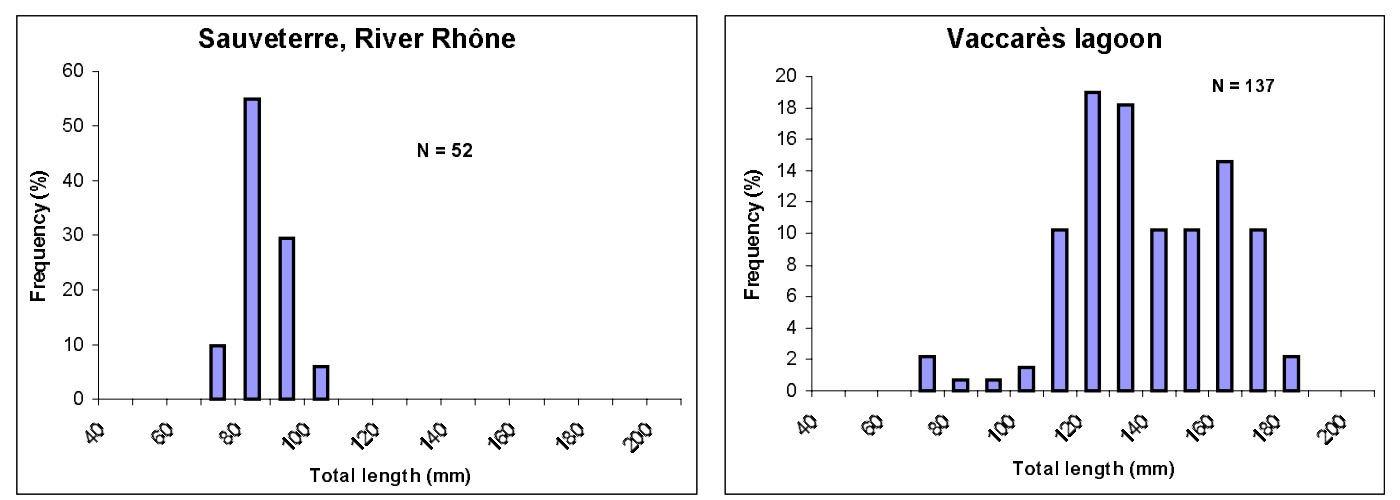

Figure 5

Comparison of the distributions of total length of YOY shad captured in the Vaccarès and in the river Rhône (GENDRE et al., 1997) in September 1994.

\section{Figure 5}

Comparaison des distributions de la longueur totale des alosons capturés dans l'étang du Vaccarès et dans la rivière Rhône (GENDRE et al., 1997) en septembre 1994. 


\section{DISCUSSION}

We have known for a long time that YOY shad occur in irrigation and drainage canals, in some marshes and in the Vaccarès and its associated lagoons, but we did not know how they entered the closed aquatic system. The most obvious explanation was that they migrated down the Rhône, dispersed in the sea in the Gulf of Beauduc and entered by the Grau de la Fourcade sluices near Saintes-Maries de la Mer. However, this explanation could not be correct as the sluices are permanently closed from June to at least OctoberJanuary. The solution was found when we started to measure the recruitment of fish into the Camargue by pumping of Rhône water for irrigation (POIZAT et al., 1999). YOY shad migrating downstream in the Rhône and are taken up by the pumps that operate 24 hours a day from April to September to irrigate the many ricefields in the Camargue. Downstream migration occurs mainly at night (O'LEARY and KYNARD, 1986). From the pumps, the YOY shad disperse quickly in the irrigation system, and pass via overfill spillways on the irrigation canals, or via the ricefields or irrigated marshes, into the drainage system. Once, there they quickly leave this habitat and swim out into the brackish Vaccarès where they stay for several months. Juveniles of this size and age (3-5 weeks) are perfectly capable of withstanding salinities of greater than $10 \mathrm{~g} / \mathrm{l}$ (ZYDLEWSKI and MCCORMICK, 1997). This route can now only take place in drainage basins that still drain to the Vaccarès; most of the drainage canals are now blocked by sluices (polderised) at their lower ends and their water is pumped back to the Rhône. The Fumemorte accounts for 55 \% of the area that is still unpolderised in the Rhône delta (CHAUVELON, 1996).

This downstream migration of YOY shad starting in mid-June is quite early for European shad in Europe in estuarine environments (CLARIDGE and GARDNER, 1978 ; APRAHAMIAN, 1988 ; TAVERNY, 1990 ; THIEL, SEPULVEDA and OESMANN, 1996). It takes place well before temperatures drop to below $19^{\circ} \mathrm{C}$ (CLARIDGE and GARDNER, 1978 ; O'LEARY and KYNARD, 1986) as has been found elsewhere LIMBURG (1996) with the American shad in the Hudson River. It is likely that this earliness is explained by the spawning grounds of Saxy on the Rhône being close (LE CORRE et al., 1997 ; LEBEL et al., 1999), about $7 \mathrm{~km}$ upstream of the town of Arles and about $30 \mathrm{~km}$ upstream of the pumps at Le Sambuc, and $55 \mathrm{~km}$ from the mouth of the Rhône. APRAHAMIAN (1988) suggested that juveniles migrate close to the shore, which would explain why they are readily taken up by the pumps in June-July, when they are still small. It is not impossible that at the end of summer and in autumn, when the YOY shad are larger, they migrate more in the centre of the river and are less vulnerable to likely to the pumps whose intakes are usually close to the shore. It seems that in the Rhône the situation is the reverse of that observed with the American shad in the Hudson River (LIMBURG, 1996), namely an early downstream migration of small sized individuals $(<5 \mathrm{~cm})$ coming from spawning sites closest to the sea and a later downstream migration of larger fish $(>7 \mathrm{~cm}$, Figure 5) coming from spawning sites further upstream. It seems unlikely that the downstream migration of YOY shad in the Rhône in June-July is controlled by the temperature (LEGGETT, 1976 ; CLARIDGE and GARDNER, 1978 ; O'LEARY and KYNARD, 1986) or the size and age of the juveniles (LIMBURG, 1996). Other, as yet undetermined factors must explain this early downstream migration.

When the length of YOY shad that grew in the Vaccarès are compared to those of other European rivers, either in the Mediterranean or elsewhere, all the lengths (with the exception of the River Neretva where there may have been methodological problems) were less than those recorded in the Vaccarès lagoon (Table II). It would be useful to validate these high growth rate observations with otoliths (counting/measuring daily increments). 


\section{Table II}

Summary of total length of shad at age one year in rivers and lakes within and outside the Mediterranean region.

\section{Tableau II}

Synthèse de la longueur totale des aloses à l'âge d'un an dans les rivières et les lacs dans et en-dehors de la région méditerranéenne.

\begin{tabular}{|c|c|c|c|c|c|}
\hline Sites & Species & Sex & $\begin{array}{l}\text { Total Length } \\
\text { at age one (mm) }\end{array}$ & Methods & References \\
\hline \multicolumn{6}{|l|}{ Mediterranean region } \\
\hline \multirow[t]{2}{*}{ River Tiber, Italy } & Alosa fallax & male & 124 & B & ANCONA (1927) in DOUCHEMENT (1981) \\
\hline & & female & 130 & & \\
\hline \multirow[t]{2}{*}{ River Po, Italy } & Alosa fallax & male & 133 & B & SERVENTI et al., (1990) \\
\hline & & female & 137 & & \\
\hline \multirow[t]{2}{*}{$\begin{array}{l}\text { River Neretva, Bosnia- } \\
\text { Hercegovina }\end{array}$} & Alosa fallax & male & 203 & B & VUKOVIC (1961) \\
\hline & & female & 214 & & \\
\hline \multirow[t]{2}{*}{$\begin{array}{l}\text { River Miliane- } \\
\text { Mejerdah, Tunisia }\end{array}$} & Alosa fallax & male & 118 & B & KARTAS (1991) \\
\hline & & female & 119 & & \\
\hline \multirow[t]{2}{*}{ Lake Volvi, Greece } & Alosa macedonica & male & 110 & B & SINIS and ECONOMIDIS (1987) \\
\hline & & female & 115 & & \\
\hline \multirow[t]{2}{*}{ River Aude, France } & Alosa fallax & male & 113 & $\mathrm{~B}$ & DOUCHEMENT (1981) \\
\hline & & female & 116 & & \\
\hline River Rhône, France & Alosa fallax & male & 124 & $\mathrm{~B}$ & DOUCHEMENT (1981) \\
\hline Lake Skadar, Serbia & Alosa fallax & $\begin{array}{c}\text { female } \\
\text { male }\end{array}$ & $\begin{array}{l}126 \\
101\end{array}$ & $\mathrm{~B}$ & $\begin{array}{l}\text { VUKOVIC (1961) in QUIGNARD and } \\
\text { DOUCHEMENT (1991) }\end{array}$ \\
\hline $\begin{array}{l}\text { Vaccarès lagoon, } \\
\text { France }\end{array}$ & Alosa fallax & $\begin{array}{c}\text { female } \\
\text { both sex }\end{array}$ & $\begin{array}{r}92 \\
183\end{array}$ & M & This study \\
\hline \multicolumn{6}{|l|}{$\begin{array}{l}\text { Outside } \\
\text { Mediterranean region }\end{array}$} \\
\hline \multirow[t]{2}{*}{ River Loire, France } & Alosa fallax & male & 115 & $\mathrm{~B}$ & DOUCHEMENT (1981) \\
\hline & & female & 118 & & \\
\hline \multirow[t]{2}{*}{ River Garonne, France } & Alosa fallax & male & 100 & B & DOUCHEMENT (1981) \\
\hline & & female & 94 & & \\
\hline \multirow[t]{2}{*}{ River Adour, France } & Alosa fallax & male & 100 & $\mathrm{~B}$ & DOUCHEMENT (1981) \\
\hline & & female & 107 & & \\
\hline \multirow[t]{2}{*}{ River Garonne, France } & Alosa alosa & male & 80 & B & $\begin{array}{c}\text { CTGREF (1979) in CASSOU-LEINS and } \\
\text { CASSOU-LEINS (1981) }\end{array}$ \\
\hline & & female & 67 & & \\
\hline River Severn, England & Alosa fallax & both sex & $67^{\star}$ & M & CLARIDGE and GARDNER (1978) \\
\hline River Elbe, Germany & Alosa fallax & both sex & ca100 & M & THIEL et al. (1996) \\
\hline
\end{tabular}

* standard length

$B=$ backcaculation or Von Bertalanffy

$\mathrm{M}=$ measurements 


\section{CONCLUSION}

An entirely artificial set of circumstances explains the unusual occurrence of YOY shad in the wetlands of the Rhône delta. It seems that the conditions encountered by YOY shad in the Rhône delta system are very favourable for fast growth (high temperature and abundance of food within the Vaccarès lagoon) which might explain that unusual YOY total length of $182.9 \mathrm{~mm}$ at the end of the growing season. YOY shad that grow in the Vaccarès are also likely to have a better survival that those fish that migrate directly down the Rhône, and contribute therefore much to the strength of a given cohort.

\section{ACKNOWLEDGEMENTS}

We thank the management associations of the Aube de Bouic, Le Sambuc and Bois d'Estaing canals and the Réserve Nationale de Camargue for allowing us to conduct the sampling and Pascal CONTOURNET, François PRIOUR, Elisabeth ROSECCHI and Olivier SOULAS for their assistance in field work. This work was funded by the Fondation Tour du Valat.

\section{REFERENCES}

APRAHAMIAN M.W., 1988. The biology of the twaite shad, Alosa fallax fallax (Lacépède), in the Severn Estuary. J. Fish Biol., 33 (Supplement A), 141-152.

BOURQUARD C., 1985. Structure et mécanismes de mise en place, de maintien et d'évolution des peuplements ichthyique lagunaires du Golfe du Lion. Thèse de 3è cycle, Université des Sciences et techniques du Languedoc, Montpellier, 337 p.

CASSOU-LEINS F., CASSOU-LEINS J.J., 1981. Recherches sur la biologie et l'halieutique des migrateurs de la Garonne et principalement de l'alose Alosa alosa $\mathrm{L}$. Thèse de doctorat, Institut National Polytechnique de Toulouse, $383 \mathrm{p}$.

CHAUVELON P., 1996. Hydrologie quantitative d'une zone humide méditerranéenne aménagée : le bassin du Fumemorte en Grande Camargue, delta du Rhône. Thèse de Doctorat, Université Montpellier II, $275 \mathrm{p}$.

CLARIDGE P.N., GARDNER D.C., 1978. Growth and movements of the twaite shad, Alosa fallax (Lacépède), in the Severn Estuary. J. Fish Biol., 12, 203-211.

DOUCHEMENT C., 1981. Les aloses des fleuves français, Alosa fallax Lacépède, 1803 et Alosa alosa Linné, 1758. Biométrie, Ecobiologie, Autonomie des populations. Thèse de 3è cycle, Université des Sciences et techniques du Languedoc, Montpellier, $377 \mathrm{p}$.

GENDRE L., MENELLA J.Y., CORRAO B., 1997. Suivi de la dévalaison des alosons, campagne d'étude 1995. MRM, $40 \mathrm{p}$.

GOURRET P., 1897. Les étangs saumâtres du Midi de la France et leurs pêcheries. Ann. Mus. Hist. Nat., Marseille, série zool., 5, 1-386.

KARTAS F., 1991. Alosa fallax algeriensis (Regan, 1916). In HOESTLAND H. (ed.), The Freshwater Fishes of Europe. Clupeidae, Anguillidae, 213-224, Aula-Verlag, Wiesbaden.

LEBEL I., BAGLINIÈRE J.L., PORCHER J.P., SABATIÉ R., 1999. Bilan des actions et des études menées par l'Association Migrateurs Rhone-Méditerranée de 1991 à 1998. MRM, 124 p. + annexes.

LE CORRE M., BAGLINIĖRE J.L., SABATIÉ R., MENELLA J.Y., PONT D., 1997. Données récentes sur les caractéristiques morphologiques et biologiques de la population d'alose feinte du Rhône (Alosa fallax rhodanensis Roule, 1924). Bull. Fr. Pêche Piscic., 346, 527-545.

LE CORRE M., LINHARES D., CASTRO F., ALEXANDRINO P., SABATIÉ R., BAGLINIÈRE J.L., 1998. Premiers éléments de caractérisation génétique de l'alose 
du Rhône (Alosa fallax rhodanensis Roule, 1924). Bull. Fr. Pêche Piscic., 350-351, 635-645.

LEGGETT W.C., 1976. The American shad (Alosa sapidissima), with special reference to its migration and population dynamics in the Connecticut River. Am. Fish. Soc. Monogr., 1, 169-225.

LIMBURG K.E., 1996. Growth and migration of O-year American shad (Alosa sapidissima) in the Hudson River estuary : otolith microstructural analysis. Can. J. Fish. Aquat. Sci., 53, 220-238.

O'LEARY J.A., KYNARD B., 1986. Behavior, length, and sex ratio of seaward-migrating juvenile American shad and blueback herring in the Connecticut River. Trans. Am. Fish. Soc., 115, 529-536.

POIZAT G., CHAUVELON P., ROSECCHI E., CRIVELLI A.J., 1999. Passage de poissons du Rhône par les pompes d'irrigation de Camargue : Premiers résultats. Bull. Fr. Pêche Piscic., 352, 31-43.

QUIGNARD J.P., KARTAS F., 1977. Les aloses feintes, Alosa fallax (Lacépède, 1803), poissons clupéiformes de l'Atlantique nord-est et de la Méditerranée : Etude des caractères numériques. Bull. MNHN, $3^{\text {ème }}$ série, 501, 1241-1256.

QUIGNARD J.P., ZAOULI J., 1980. Les lagunes périméditerranéennes. Bibliographie ichtyologique annotée. Première partie : les étangs français de Canet à Thau. Bull. Off. natn. Pêch., Tunisie, 4, 293-360.

QUIGNARD J.P., ZAOULI J., 1981. Les lagunes périméditerranéennes. Bibliographie ichtyologique annotée. Deuxième partie: b) les étangs français d'Ingril à PortoVechio. Bull. Off. natn. Pêch., Tunisie, 5, 41-96.

QUIGNARD J.P., DOUCHEMENT C., 1991. Alosa fallax lacustris (Fatio, 1890). In HOESTLAND H. (ed.), The Freshwater Fishes of Europe. Clupeidae, Anguillidae, 257-264, Aula-Verlag, Wiesbaden.

RAMEYE L., KIENER A., SPILLMANN C.P., BIOUSSE J., 1976. Aspects de la biologie de l'alose du Rhône - Pêche et difficultés croissantes de ses migrations. Bull. Fr. Piscic., 263, 50-76.

SERVENTI M., VITALI R., GANDOLFI G., 1990. Biologia e biometria dei riproduttori di alosa, Alosa fallax (Lacépède), in migrazione nel delta del Po. Rivista di Idrobiologia, 29, 469-475.

SINIS A.I., ECONOMIDIS P.S., 1987. Age and growth of Alosa macedonica (Pisces: clupeidae), of the lake Volvi (Macedonia, Greece). Vest. Cs. Spolec. Zool., 51, 4357.

TAVERNY C., 1990. An attempt to estimate Alosa alosa et Alosa fallax juvenile mortality caused by three types of human activity in the Gironde Estuary, 1985-1986. In VAN DENSEN W.L.T., STEINMETZ B. and HUGHES R.H. (Eds.), Management of Freshwater Fisheries, 215-229, Pudoc, Wageningen.

THIEL R., SEPULVEDA A., OESMANN S., 1996. Occurrence and distribution of twaite shad (Alosa fallax Lacépède) in the lower Elbe River, Germany. In KIRCHHOFER A. and HEFTI A. (Eds), Conservation of Endangered Freshwater Fish in Europe, 157-170, Birkhäuser Verlag, Basel.

VUKOVIC T., 1961. Populacije i mrescenje Alosa fallax nilotica (Geoffroy) u vodama Neretva is Skadarskojezera. Godisnjak Bioloskog Instituta Univerziteta u Sarajevu, 14, 85-178.

ZYDLEWSKI J., MCCORMICK S.D., 1997. The ontogeny of salinity tolerance in the American shad, Alosa sapidissima. Can. J. Fish. Aquat. Sci., 54, 182-189. 